\title{
The Effect of Globalization, Labor Fexibilization and National Industrial Relations Systems on Human Resource Management
}

\author{
Mohammad Ziaul Hoq (Corresponding Author) \\ Faculty of Business and Accountancy \\ University of Malaya \\ 50603 Kuala Lumpur, Malaysia \\ Tel: 60-17-269-5947Ｅ- mail: hoq.ziaul@gmail.com \\ Muslim Amin \\ Faculty of Science and Technology, University Kebangsaan Malaysia \\ Bangi, Selangor, Malaysia \\ Ifthekhar Amin Chowdhury \\ Faculty of Business Administration, Daffodil International University \\ Dhaka, Bangladesh \\ Sulaiman Ali \\ Faculty of Economic, University of Syiah Kuala \\ Banda Aceh, Indonesia
}

\begin{abstract}
This paper analyzes how changes to the global organization of capitalism have accompanied and intensified globalization as well as have affected the regulation of labor and employment relationship. One of the most significant of these changes has been the dramatic increase in the rate of cross-border merger and acquisition activity. Of equal significance, especially for the regulation of labor and the employment relationship, has been the pronounced tendency of global enterprises to transform themselves into coordinators and organizers of activities performed for them by contractors, sub-contractors and suppliers. Outsourcing and subcontracting have allowed global enterprises to reduce and externalize the costs incurred from the direct employment of labor. This reorganization of the operations of global corporations has been greatly facilitated by the removal of barriers to trade and the global movement of capital, and labor market deregulation. Labor market deregulation has largely been brought about by the emasculation of national Industrial Relations Systems (IRSs) in developed and developing nations alike. As national IRSs have been emasculated, so has the regulation of labor and the employment relationship increasingly been internalized in the firm by the use of Human Resource Management (HRM).
\end{abstract}

Keywords: Globalization, Global capitalism, Labor Fexibilization, National Industrial Relations System, HRM

\section{Introduction}

With increasing globalization there have been enormous and far-reaching changes in the global organization of capitalism. These changes are the result of the fierce international competitive pressures faced by enterprises operating in the global marketplace. One of the most significant changes has been the dramatic increase in the rate of global merger and acquisition (M\&A) activity. Another has been the pronounced tendency of global enterprises to reorganize their operations so that they are transformed into coordinators of activities performed on their behalf by others. The sub-contracting and outsourcing of operations, particularly the more labor intensive ones, enable firms to reduce their overheads by externalizing the capital and other costs associated with the direct employment of labor. Naturally, outsourcing and subcontracting have resulted in the lengthening, indeed the globalization, of supply chains which have accordingly also grown in complexity. Globalization, and the development of global capitalism, has been greatly facilitated by, amongst other things, the reduction or removal of trade barriers, and the drastic weakening of barriers to the global movement of capital. Labor market deregulation, reflected in the emasculation of national Industrial Relations Systems (IRSs), has also contributed to increasing and accelerating globalization.

Corresponding to the tendency national IRSs has been the trend to internalize labor regulation within the enterprise. Human Resource Management (HRM) is increasingly used by global enterprises as a regime of labor regulation tailored 
to the requirements of the individual firm. The growing dominance of HRM in the regulation of labor and the employment relationship has occurred in tandem with the increasing flexibilization of labor. The workforce of the global enterprise is increasingly divided into core workers and peripheral or flexible workers. The core workers are generally highly skilled professionals directly employed by the enterprise in its global headquarters, usually located in the one of the advanced industrial countries. These workers are usually, fulltime, permanent employees who are relatively well paid and receive other attractive rewards and entitlements. In contrast, the peripheral workers are not employed by the enterprise itself, but by its sub-contractors and suppliers. They are generally part-time or intermittent workers on low casual rates of pay. They are also generally women. Employment growth in the less developing countries over the past several decades, as well as in the advanced industrial countries over the same period, has seen a spectacular increase in the size of the flexible, female labor force rather than in the ranks of fulltime employees.

If we consider the case of Bangladesh, we can find that the part time or temporary workers are increasingly dominant in the business environment. For example, many of the banks and insurance companies employ part time or temporary executives for selling or promoting their services (i.e. telephone banking, credit cards and insurance policies etc.). Mobile phone companies are hiring part time employees to provide customer services. In IT industry companies employ part time data entry operators, graphic designers and website developers etc. Recently we have observed that fast food and restaurant industry is very much ahead in employing part time workers for rendering services and working as kitchen hand. Pizza Hut is an example of successfully using the peripheral workforce. The employees of the fast food industry normally perform one particular type of activity all day long for 5 to 6 days of a week. In other industries like universities, colleges and sports clubs part time professional personnel play a key role with the full time professional personnel. On the other hand some historically female oriented industries of Bangladesh are also employing male employees at present. Previously in garments industry, most of the jobs suited female workers and were offered only for female workers, but at present garments industries are also offering production floor jobs as well as decision-making jobs for males.

HRM is used as an internal system of labor regulation by enterprises to regulate the employment of their core workforce. On the other hand, it is also used as a system of labor regulation to regulate the employment of the enterprise's peripheral or flexible workforce. In other words, it regulates the employment of workers employed by contractors, sub-contractors and suppliers right along the length of the supply chain. For the core workforce, HRM is cooperative, inclusive and participatory in orientation, concerned as it is with winning the individual commitment of core employees to the enterprise and the achievement of its strategic objectives. It emphasizes performance, skills and individualized monetary rewards. For the peripheral workforce, in contrast, HRM emphasizes short term and insecure employment, low hourly rates, degrading conditions of employment, lack of opportunities for training and career advancement, and so on. But it is also about "improving" the performance of the flexible workforce by speeding up or reducing the piece rate or casual hourly rates received by flexible workers, and offering them only intermittent employment, but at the same time extending the length of the working day.

This paper further argues that it is not only enterprises operating in the global economy, which have been affected by global competitive pressures. Globalization has subjected firms, which serve only national domestic markets, and even those which service local and niche markets, to exactly the same pressures as those their global counterparts face. As a consequence, such firms are under duress to organize production in exactly same way as global business enterprises organize production.

\subsection{Objective of the study}

- $\quad$ To examine recent trends and developments in global capitalism and analyze how these have led to the 'flexibilization' of worker and employment .

- To examine how globalization and flexibilization have given rise to the emergence of HRM as a system of labor regulation within the enterprise

- $\quad$ To compare HRM and national IRSs as systems of labor regulation.

- $\quad$ To provide insights for policy formulation in the era of globalization.

\section{Methodology}

The article has been written on the basis of secondary information. The secondary information were collected from published books, journals, research papers, and official statistical documents, most of which were published during the period of 1970- 2006.

\section{Globalization and Global Capitalism}

When we speak of global capitalism, then, we refer to a variant sub mode of capitalism that can be distinguished from two other variants extant in both present and past capitalist social formations- the competitive and monopoly variants. Capitalist social formation almost always includes more than one variant of the capitalist mode of production as well as pre-capitalist social relations. At any given time, however, one variant can be identified as dominant in relation to others. 
In terming the contemporary era one of global capitalism, we are suggesting that the global variant, and thus global firms, are emerging as dominant in relation to firms that continue in monopoly or competitive sectors of the social formation.

Scholte (2000) argues that on the one hand capitalism has been a primary cause of globalization, but on the other hand the global capitalism has been one of its main consequences. Globalization has greatly strengthened capitalism to the extent that it is the prevailing, and largely unchallenged, structure of production and exchange across the globe. Surplus accumulation has been extended to the consumer, finance, information and communications sectors. The extension of surplus accumulation into these sectors has been accompanied by major shifts in the organization of capitalism, including the rise of offshore centers, trans-border companies, corporate mergers and acquisitions, and oligopoly (Scholte, 2000).

Knudsen (2001) observes that Multinational Enterprises (MNEs), or Transnational Corporations (TNCs), are increasingly responsible for the initiation and organization of global economic activities. In 1996, it was estimated that there were about 44,000 TNCs in existence worldwide (Global Governance Reform Project, 2000, p. 34). These are "parent" TNCs that controlled about 280,000 affiliated organizations, of which 7,000 were 'home-based' in the fourteen major developed OECD countries, 90\% having their headquarters in the countries of the developed world (Hirst and Thompson, 1999, p. 68). Fifty of the 100 largest economies are not nation states but TNCs. Only the largest developing country economies, such as India and the People's Republic of China, are included in the 50 largest economies. Moreover, "1\% of TNCs now account for $50 \%$ of world FDI" and $70 \%$ of global trade is controlled by a mere 500 TNCs (Malhotra, 1998). The global dominance of large corporations is also reflected in employment figures, with approximately one in five employees in the developed countries directly employed by TNCs. When subcontracted and franchised operations of TNCs are factored in, the proportion rises to about two-fifths (Knudsen, 2001).

Cross-border mergers and acquisitions account in large part for the spectacular growth in size and influence of TNCs over the last several years. Such acquisitions and mergers have direct and profound implications for a TNCs workforce in all the countries in which it operates.

Knudsen(2001) points out, by becoming multinational and by acquiring additional plants, a company increases its ability to apply 'divide and rule' tactics and practices in its dealings with the workforce. These tactics are particularly effective in situations where a company produces the same or very similar products at different sites. Using techniques such as benchmarking, a company collects comparative information on productivity and performance at its several plants and on this basis makes decisions on levels and types of investments. Not surprisingly, investment decisions favor those sites where productivity and performance are best, while the poorer performers face disinvestment or even closure (Knudsen, 2001).

\subsection{HRM issues and challenges in global markets}

The coming of the 21 st century globalization poses distinctive HRM challenges to businesses especially those operating across national boundaries as multinational or global enterprises. Global business is characterized by the free flow of human and financial resources especially in the developed economies of European Union (EU), the North American Free Trade Agreement (NAFTA), other regional groupings such as the Association of South East Asian Nations (ASEAN), the Economic Community of West African States (ECOWAS), the Southern African Development Community (SADC), etc. These developments are opening up new markets in a way that has never been seen before. This accentuates the need to manage human resources effectively to gain competitive advantage in the global market place. To achieve this, organizations require an understanding of the factors that can determine the effectiveness of various HR practices and approaches. This is because countries differ along a number of dimensions that influence the attractiveness of Direct Foreign Investments in each country. These differences determine the economic viability of building an operation in a foreign country and they have a particularly strong impact on HRM in that operation. A number of factors that affect HRM in global markets are identified: (1) Culture (2) Economic System (3) Political System - the legal framework and (4) Human capital (Noe, et al, 2000). Consistent with the scope of the present paper, only one dimension is treated: human capital (the skills, capabilities or competencies of the workforce). This is in consonance with the believe that competency-based human resource plans provide a source for gaining competitive advantage and for countries profoundly affect a foreign country's desire to locate or enter that country's market (O'Reilly, 1992). This partly explains why Japan and US locate and enter the local markets in South East Asia and Mexico respectively.

In the case of developing countries, globalization poses distinct challenges to governments, the private sector and organized labor. These challenges, which must be addressed through a strategic approach to human resource management, include (1) Partnership in economic recovery especially in South East Asia (2) Dealing with the "big boys", the fund managers (3) Concerns over possibility of fraud in E-commerce (such as issues of confidence and trust) and (4) Implementing prescriptions for recovery and growth taking in to consideration the development agenda and unique circumstances of individual country. 


\subsection{Globalization and consequences for workers and work places}

\subsubsection{The impact of new information technologies}

Technological innovation has always been an important factor of change in work. But changes due to the world-wide and wholesale introduction of new information technologies (NIT) in work have particularly important impacts, in part in promoting and speeding up globalization, in part of recurrently influencing work settings.

One consequence of NIT has often been noted: the switch from physical work demands to mental, information handling, "intellective" operations with their concomitant stressors like undue increase of mental workload. This virtualization of work and the switch from physical to mental activities has been labeled by Zuboff (1984) as decasualization of work. New technologies in work settings imply changed competence demands, a new division of local labor, and organizational change. The history of work in the twentieth century is a history in which machines have increasingly replaced the skills of workers of all collars. In a production process in which science and technology are central, knowledge and not skill defines the process (Aronowitz and DiFazio, 1994:92). In order to realize how fast and dramatic these technical changes occur it is sufficient to remind ourselves that it is only since the 1980s that the computer began to enter our work and private life to any noticeable extent. Today, practically every second work place in many parts of the world is affected by the "smart machine". New information technologies have also transformed the work life for staff in universities. Most university employees spend many hours daily in front of the computer screens. Daily they are linked to their colleagues through often real-time e-mail and internet contacts. Literature search is conducted by scientists themselves through search machines in the www. The division of labor in university departments changes. Secretaries no longer need to type because scientists usually write their papers and letters themselves. Secretaries become office assistants and office managers.

Thus, the World-Wide-Web and the introduction of new and capital intensive NIT in work settings may be considered as a central precondition for globalized information access and communication. It implies the possibility of breaking down the traditional unity of time and place in work. Flexibilization of working time and the increased possibility to achieve one's work by telemetric (Andriessen and Roe, 1994) and independently of a specific physically determined workplace offer the work force opportunities of self-determined planning and self-determined learning. This increase in autonomy is bound to have repercussions for the distribution of power in work settings as well as in families. The whole fabric of society is affected by this new flexibility.

We are confronted here with a curious irony of history. After all, the introduction of new technologies and the concomitant increase of automation in work followed the rationale of making the production process more controllable and more independent of human action. But due to the drastic increase of capital intensity of high-tech workplaces, workplaces also become more vulnerable due to the possibility of human error or sabotage. Hence, ironically, the opposite of original expectations takes place: work becomes ever more dependent on responsible, competent, and committed human work activity. Add the world-wide increase of competition and the experience of workers to be dependent on the success of their company in order to remain employed, and then we understand why those still employed are characterized by high motivation to work diligently. Threatened by unemployment people work harder. The protection and intermediate brokerage of unions becomes more and more obsolete (Streeck, 1996).

\subsubsection{Changing work structures in industrialized countries}

However, world-wide changes in technology not only induce changes in work places, but they also engender dramatic changes in the occupational structure and the professions. We observe world-wide the emergence of new professions which is accompanied by the growing obsolescence and sometimes wholesale disappearance of traditional professions. In consequence, career patterns must change; inter-professional mobility and frequent professional changes in one's life time are required. More importantly, these new professional categories do not follow the received professional classifications and they do not correspond any more to traditional vocational and professional educational or training programs. We note here a remarkable uncoupling of work and professional demands in the economy from the existing educational system.

Unemployment, as a characteristic of labor market structure, is one of the most prominent crisis symptoms of many Western industrialized societies. Although still claimed by many economists or politicians, this is not a consequence of economic cycles but a structural phenomenon resulting from technical progress and ensuing productivity increases which sometimes reach $200-300 \%$. There is no question that labor productivity, if it is measured as a ratio of a unit of output to the time required for its production, has increased dramatically (Aronowitz and DiFazio, 1994). We observe a growth in productive capacities which makes "living work" (Marx), the demand for work of real people redundant. Both, global competition and outgrown productive capacities appear to be the main drivers of unemployment.

At least in Germany the daily news about the growth of unemployment figures and the imminent wiping out of jobs is staggering. Cybernetics is the most widely applied current means by which labor is being progressively freed (without 
pay) from the industrial, commercial, and professional workplace (Aronowitz and DiFazio, 1994:82). Sometime ago, it was possible to read, within a time span of a couple of days, the following alarming news in German papers:

- Deutsche Bank reduces workforce by 6400 .

- Association of German Banks announces to lay-off more than 5000.

- More than 5-7 million unemployed persons in Germany.

- Some regional unemployment rates reach more than $20 \%$.

- Opel intends to reduce staff by 6000 .

A split goes through most European societies. A split between those who still own workplace and those who do not. This is true for many of the so-called developing countries as well. The ratio of those deprived of a job is increasing. Some people speak of a two-thirds society; two-thirds living on the sunny, one third living on the shady side. Our societies are marked by a gap of social justice when we consider the distribution of work. Given the continued productivity growth in our economies, this trend is likely to continue even if it is periodically interrupted and temporarily even reversed. One important index of this development is also the steady erosion of traditional fixed work contracts in favor of more flexible work arrangements and self-employment. This growing casualization of work contracts (i.e. the reduction of safeguards against firing, the growth of part-time employment and temporary work agencies and the demise of life-long employment policies) is indeed a reflection of the predicament of work in our societies.

And yet, our societies define themselves as work societies. Almost half a century ago, Hannah Arendt (1958), one of the most important German philosopher of the 20th century, has heralded the troublesome problem of a society without work:

However, since the 1930s we know from the work of psychologists that the unemployment experience creates conditions for health hazards and deteriorating physical and mental health (Jahoda et al., 1960 and Warr, 1984).

When discussing work in society we can distinguish at least four perspectives (MOW, 1987):

- The philosophic-anthropological meaning of work as a fundamental human condition in the sense of Hannah Arendt;

- the objective societal significance of work as the central societal means to create and maintain culture;

- the economic role of work as the central mechanism for the distribution of goods and social opportunities; and, finally,

- the subjective, psychological meaning of work in the context of other life roles.

Already Durkheim (1960) considered work and the social division of labor as the fundamental connection among humans creating the basis for social integration. In line with Arendt, also similarly Anthony (1980) raised the questions - what is to the course and the foundation of moral order when work ceases for many or diminishes for most? If men enter society through work what will be left of society if work ends? Is it possible that man will become truly alienated from other men only when he is released from work which was said to have alienated him?

Thus, we may conclude that beyond the mere provision of income to cover basic needs, it is through the social bonding of work which links individuals to society, gives them social standing and status, serves as a basis for the construction of their personal identity. Given our cultural heritage, work is for most an existential necessity, providing livelihood and meaning in life.

As to migration: the issues that need to be addressed in connection with international migration range from basic human rights and political problems of citizenship over health issues, social rootlessness and dual ethnic loyalty of migrants and their offspring to ethnic revival and politicization of minorities in response to xenophobic radicalization of the work force (Wilpert, 1989). The entry of foreign workers also raises issues such as how European or US managers and regulators deal with the proliferation of immigrant workshops and sweatshops, which threaten to reintroduce the poor labor conditions of 19th Century Europe and 20th Century Asia into the back streets of Europe and the US. We deal here with workers who have come into our own countries (legally and illegally) from poorer countries and take the dirty jobs in our companies at low pay and often without health and retirement benefits and face many stresses and acculturation problems for themselves and their families (Oppen, 1988, Collatz, 1992 and Wilpert, 1998). Do they have the same rights as our citizens to workplace health and safety, and if they do not, what is being done or should be done? And if they have the same protections and rights but don't know how to use them, how should we adapt our regulations and policies to help them?

Women face particular problems in the migratory process. Half of the estimated 120 million migrants world-wide are women. Women generally add to the predicament of male unemployment: One of the most serious - and ironic consequence of the feminization of the new proletariat has been to increase the pool of wage laborers and thus 
contribute to male unemployment (Sassen, 1998). And it is an epochal trend towards increasing female labor market participation. But it is mainly migrant women who fill poorly paid jobs in receiving countries as domestic workers, as nannies and housekeepers, as sex workers while often being separated for years from their own families and children in their countries of origin (Ehrenreich and Hochschild, 2003).

\subsubsection{Changing work structures in developing countries}

While unemployment in industrialized countries is one of their major labor market characteristics, other problems are posed in the mean and long-term perspective for countries in the so-called Third World regions. Import of highly developed production technologies and rapid industrialization processes meet country contexts which may be far from offering appropriate receptive conditions for a balanced and sustained development (see the series of annual reports on human development by the United Nations Development Program - UNDP). Further, an unabated influx of migrants from rural areas to metropolitan centers in Third World countries creates a growing urban under-educated and under-employed proletariat on the one hand and the emergence of new elites who have mastered the new work performance demands and requisite new technologies which make their integration in the globalized economy possible, while, at the same time, contributes to growing rifts and disparities in the social fabric of the population in the developing countries.

\subsubsection{Changing industrial relations systems}

There can be no doubt that also the industrial relations system is drastically affected by competition in all world markets. Particularly, institutionally and statutorily regulated systems of industrial relations are threatened, because under prevailing conditions companies find it easier than before to escape from demanding regulatory frameworks such as the traditional German system of codetermination. As a consequence, more voluntearistic rather than obligatory systems emerge and social partners (unions and employers organizations) are predicated in their activities less institutionally than by market forces. Employment conditions are more and more determined by company policies rather than general statutory rule systems (Streeck, 1996). The general decline of union membership appears in this context as a reflex of the work force which perceives little protective potential in unions. In short: industrial relations systems, too, undergo critical changes.

By the way of an interim summary: Change, the disruption of continuity, the tearing of social fabric, uncertainty and an upheaval in all life spheres seems to be the endemic effect of globalization. "What's peculiar about uncertainty today is that it exists without any looming historical disaster; instead it is woven into the everyday practices of a vigorous capitalism. Instability is meant to be normal" (Sennett, 1998:31).

\section{Globalization and the 'Flexibilization' or 'Informalization' of Work}

Scholte (2000) observes accelerated globalization in recent decades has affected not only the opportunities for waged employment, but also the conditions of work. What he calls the 'flexibilization,' other commentators have termed the 'in-formalization,' of work has been a particularly insidious development. The manner in which human resources are deployed in the workplace, working practices and wages, labor mobility, and the range of tasks an individual worker is routinely called on to perform have all been affected by flexibilization. Indeed, while labor flexibility has many guises, these can all generally be fit into one or other of the following categories:

1) Reducing the core of permanent workers

2) Increasing the proportion of temporary and casual employees [also known as peripheral workers]

3) Increasing the use of women, apprentices and migrants

4) Subcontracting the production of components previously manufactured within the factory

5) Subcontracting services like transport, packaging, maintenance, security, etc., which are carried out on factory premises

6) Increasing the number of shifts per day or the use of overtime; replacing pay systems based on working time and length of service by systems based on piece rates and bonuses

7) Introducing internal training systems which facilitate redeployment of workers within the factory or enterprise [also known as multi-skilling] and

8) Reducing influence from external trade union organization by either eliminating unions or establishing a controllable [company] union.

The version of globalization with which we all have had to become familiar owes much to the hold which neo-liberal ideas, strategies and policies have had over governments and policy makers in the developed world, and increasingly in the underdeveloped countries as well. As far as work and employment are concerned, the growing global demand for flexible labor which has accompanied globalization has been generated by "The deregulation of labor markets, fragmentation of production processes, de-industrialization and emergence of new areas of export specialization" (Kanji 
and Menon Sen, 2001, p. 1-2). But this is only half the story. The increased demand for flexible labor has meant the feminization of labor-the prodigious growth in the numbers of low-paid, flexible female workers around the world. Jobs growth in the advanced industrial economies over recent years has been predominantly in the area of part-time and casual work. Women's employment opportunities have accordingly been restricted to such jobs, which are generally defined as unskilled or semiskilled.

Flexible jobs have proliferated in leading sectors of the global economy, such as retail, hospitality, information and communications, and banking and finance. They have also proliferated in the traditional sweated trades and industries, such as textiles and clothing, and increasingly in the industrialized countries as well. Flexibilization has also accompanied the deindustrialization of the older industrial cities and regions, and relocation of process, assembly and other labor-intensive operations to the low-wage countries. The introduction or relocation of production facilities to green field sites in cities and regions with no prior history of labor activism and union militancy has been a parallel development. Flexibilization has also become more widespread as has the widely perceived need for enterprises, industries and national economies to remain globally competitive become more and more imperative. Managers and workers alike have generally had to accept that improved wages and working conditions and more stable employment arrangements would undermine the competitiveness of the firm and lead to production and other operations moving offshore (Scholte, 2000).

\subsection{Globalization, Flexibilization and Human Resource Management (HRM)}

As suggested above, with increasing globalization, the international competitiveness of enterprises has become a crucial factor in their survival and growth. This is true not only for firms that operate in the global marketplace, but also for firms whose scope of operations is restricted to the national economy of a particular country and even for those that only service local or niche markets. The removal or reduction of trade barriers, dismantling of the barriers to the global movement of capital, the growth in size and influence of TNCs, and the widespread availability and use of communication, information and transportation technologies that make global transactions possible have together ensured that all firms regardless of their scope of operations are now subject to global competitive pressures. Sriyan De Silva (1998) points out in this regard that Enterprises driven by market pressures need to include in their goals improved quality and productivity, greater flexibility, continuous innovation, and the ability to change to respond rapidly to market needs and demands. Directly in line with this trend, the quality of a firm's "human resources" (employees or workers) is now a crucial ingredient in its overall competitiveness in the global economy.

The growing significance of self-management, and the corresponding decline in direct control, in modern enterprises should not be allowed to obscure the fact that HRM is an important, often indispensable, means of achieving management objectives. While employees are encouraged, even rewarded, for identifying with the enterprise and for helping it to achieve its objectives, the vast majority have no effective role in management and play virtually no part in defining the enterprise's objectives (Rix, 2001). As the quality of an enterprise's human resources becomes an increasingly important factor in its international competitiveness, so does HRM attain a more dominant position in the enterprise's overall management structure and decision-making. This is a trend which clearly demonstrates a change in power relations and highlights the supremacy of management. The management prerogative is rediscovered but in place of command and control the emphasis is on commitment and control as quality, flexibility and competence replaces quantity, task and dumb obedience. To put it another way: the managerial agenda is increasingly focused on innovation, quality and cost reduction. Human resource management makes more demands on employees, work is intensified ...there is less room for managerial slack and for indulgency patterns (de Silva, 1998).

The foregoing should make it abundantly clear that HRM is in no way to be confused with what de Silva calls the "traditional personnel function." Unlike the personnel function, HRM is fully integrated into strategic management, concerned as it is with ensuring that the enterprise's human resources are deployed in such a way as to ensure their commitment and contribution to the strategic objectives of the enterprise. Instead of emphasizing "problem-solving and mediation," HRM is chiefly interested in incorporating the enterprise's human resources into corporate strategy and planning. Employee participation and cooperation are facilitated by "programs of corporate culture, remuneration packaging, team building and management development for core employees, while peripheral employees are kept at arms length" (de Silva, 1998).

Scholte (2000) points out that globalization has had a decidedly corrosive effect on employment security. He also argues that the "economic logic" of flexibilization is highly questionable, leading to reduced rather than enhanced efficiency and competitiveness. Workers who are well trained, well-paid and who have stable and secure jobs may well be more "motivated, reliable and productive" than 'flexible' or 'irregular' employees. He notes that "To this extent the 'race to the bottom' in wages and other working conditions could operate not only against human security, but against efficiency as well" (Scholte, 2000).

According to Gallin (2000), the emergence and development of a global labor market is the most important social consequence of globalization. Capital mobility and the rapidity and reach of communications networks, at once 
important causes and consequences of globalization, mean that workers in all countries, including the industrially advanced nations, are competitively underbidding each other in an unseemly, and from the point of view of efficiency and productivity, counter-productive global race to the bottom. As seen above, this underbidding has set in motion a relentless downward spiral of deteriorating wages and conditions through competitive deregulation and informalization of work. But, as the traditional "core" labor force shrinks in industrialized countries, there is no quid pro quo in terms of balanced social and economic development for the industrially underdeveloped countries, where unemployment is a massive and growing problem and where wages remain below poverty level in most cases. One of the reasons has been the ability of transnational capital to impose conditions on states by the threat of relocation if its conditions are not met; another related and underrated reason is state repression, which keeps in place the near slave-labor conditions that prevail at the bottom of the scale (for example in many of the Export Processing Zones (EPZs) in countries such as China, Indonesia or Vietnam) (Gallin, 2000).

The changing structure of transnational enterprises largely accounts for the rise of 'flexibilization' or 'informalization.' As Gallin (2000) notes, the transnational enterprise organizes work carried out for it by others. At the head of the corporation is the corporate headquarters, which directs production and sales, controls subcontracting, decides at short notice what will be produced where, when, how and by whom, and where certain markets will be supplied from .It is here that management and the core labor force of highly skilled technicians and others will generally be located. Production and all other labor-intensive operations are outsourced and subcontracted, the company being essentially a coordinator of elaborate, cascading chains of outsourced production.

These subcontracted operations are not part of the corporation's formal structure, but will nevertheless be wholly dependent on it, with wages and conditions deteriorating when moving from the centre of operations to the periphery (Gallin, 2000). The majority of workers in the developing countries, and a considerable and growing proportion of the labor force in the developed, industrialized countries, are employed in the informal sector.

\subsection{HRM and National Industrial Relations Systems (IRSs)}

Fleming and Seborg (2001) points out that the governance and regulation of the relations between management and labor are determined both by a country's Industrial Relations System (IRS) and the HRM policies and practices of individual firms. The elements of a national IRS are largely determined by actors, institutions and forces external to the enterprise, namely, the legislative and regulatory framework covering industries and labor markets set by government, and by the collective agreements between management and organized labor established within this framework (Fleming and Soborg, 2001). It should not be forgotten, of course, that there is a sort of international IRS in existence, with the minimum labor standards of the ILO at its core. However even here, as Fleming and Soborg (2001) observe, the ILO minimum standards require recognition and implementation within national IRSs in order to be effective. A more effective international IRS would require, amongst other things, greater international coordination of decision-making and more concerted action by nationally-based unions and peak union bodies. The International Trade Secretariats (ITS) of the International Confederation of Free Trade Unions (ICFTU) are attempting to construct a more effective international IRS for all countries, developing and developed, but they, too, are limited by the weakness of organized labor in many countries, developed and developing, and by the consequent weakness of organized labor at the international level.

Unlike the various national or international systems of industrial relations, HRM is mainly determined internally in the corporation or organization, on plant, business area or global level (Fleming and Seborg, 2001). Whereas the institutions and practices of traditional industrial relations, such as collective bargaining, require the existence and active involvement of trade unions, these are a very long way from being preconditions for the formulation, development and successful implementation of HRM policies. Indeed, the successful implementation of HRM programs, including those dealing with selection and recruitment, leadership and motivation, remuneration, competency development and training, and employee retention, can be achieved without the presence, consent or cooperation of trade unions. Nevertheless, as de Silva (1998) remarks, this is not to suggest that unions should not be involved where they exist... [indeed] they have worked best in a unionized setting.

While trade unions obviously do and should have a role to play in the successful implementation of HRM programs, this must not be allowed to obscure the fundamental differences between HRM and Industrial Relations (IR) approaches to the employment relationship. As de Silva (1998) notes, IR is essentially pluralistic in outlook, in that it covers not only the relations between employer and employee (individual relations) but also the relations between employers and unions and between them and the State (collective relations). IR is also pluralist in that it recognizes that conflict, or at least disagreement, in the employment relationship is inevitable given the competing and often opposing interests of employers and employees. It is this concern with collective relations and conflict which really sets IR apart from HRM, and also explains why IR is so concerned with such institutions and practices as labor law, labor standards, collective bargaining, trade unionism, and so on. 
Unlike IR, HRM is essentially unitary in outlook in that it assumes a convergence or commonality of interests between employees and employers. HRM, moreover, sees the employer-employee relationship as an individualized one and, therefore, increasingly places emphasize on monetary rewards linked to performance and skills through the development of performance and skills-based pay systems, some of which seek to individualize monetary rewards (e.g. individuals bonuses, stock options, etc.) (de Silva, 1998). The cooperative, inclusive and participatory HRM programs mentioned above are also concerned with winning the individual commitment of employees to the enterprise, its philosophy, values and objectives.

MNCs will commonly use HRM as part of a global strategy to bring about convergent labor-management relations within the various plants and operations of the firm regardless of where they are located around the world. In such circumstances, the actions that unions can and do take are largely governed by the national IRS. Corporate managers, on the other hand, are becoming less and less subject to these national constraints but have to be much more attentive to the global HRM strategies not only of their own enterprise but those of their competitors as well. From the corporate point of view, the reasons for this are compelling that HRM can be seen as a more flexible and effective instrument to use and develop labor resources. Industrial Relations (IR) system based on employers' and employees' rights (or restrictions of rights) as citizens. Thus IRS has a broader public and civil society dimension involving the state which is absent in HRM. HRM regulation is mainly internal to a global company. Very little is open to public scrutiny and debate, which from a management point of view may give more flexibility and freedom. The typical contractual regulation in IRS is too limited an instrument for management to maximize productivity, competence development and creativity of labor (Fleming and Soborg, 2001).

There is no doubt that, as Fleming and Soborg (2001) points out, HRM is attractive to management precisely because of its flexibility and effectiveness in the deployment and development of labor resources. Beyond this, because HRM is in effect a labor regulatory system internal to a company, it avoids or circumvents the rights-based legal regulations of national IR systems. It is well known, of course, that the appeal of HRM has grown just as governments, particularly those in the industrialized countries, have deregulated their national labor markets. Not surprisingly, this has generally entailed the dismantling of the national IRS which, because as it accorded rights to labor and management, increased even if it did not raise to power the bargaining power of labor vis-à-vis management. As noted above, HRM reinstates managerial prerogative generally (but not always) without the reintroduction of command and control systems. Thus, the dismantling of national IRSs reduces the bargaining power of labor allowing corporations to introduce HRM regimes virtually unimpeded. The HRM regime is tailored to the particular needs and circumstances of the individual corporation, and can be easily varied as those needs and circumstances change. TNCs and domestic companies alike benefit from labor market deregulation and the dismantling of national IRSs. HRM is attractive to both sorts of company because they are each subject to the same global competitive pressures. The growing dominance of HRM in the regulation of labor and the employment relationship has occurred in tandem with the increasing flexibilization of labor.

As seen above, the deregulation of the labor market and dismantling of the IRS (to the extent that these are separate processes) have given rise to the flexibilization of the employment relationship. There has been a corresponding shift by businesses of all sizes to the use of HRM policies and practices to internalize the regulation of labor within the enterprise. However, where firms have outsourced their labor-intensive operations to contractors and subcontractors, it is not so much that labor regulation is internalized within the firm itself, rather that it is internalized within the entire supply chain and along its entire length.

For the shrinking numbers of core workers within the enterprise, it is about performance, skills and individualized monetary rewards. For the peripheral workers-those employed by contractors, sub-contractors and suppliers-on the other hand, HRM is about short term and insecure jobs, low piece rates, lack of opportunities for training and career advancement, and so on. But it is also about performance-getting more for less by the intensification of work (speeding up, a reduction in the piece rate or casual hourly rate, etc.).

\section{Conclusion}

Globalization has subjected global companies and companies servicing national and local markets to the same competitive pressures. These pressures have led to the restructuring of global and national enterprises and the reorganization of production, in particular, the outsourcing and sub-contracting of labor-intensive operations. HRM has been widely adopted as a system of labor regulation within the firm and along the length of the supply chain, rising to dominance as national IRSs have declined in strength and significance. The rise to dominance of HRM has been accompanied by the division of the workforce into a shrinking group of core workers and a rapidly growing corps of peripheral or flexible workers, most of who are female workers. The firm at the top of the supply chain determines the employment conditions of the flexible workers, who are employed by the contractors, sub-contractors and suppliers to the top firm. Governments and trade unions have an absolutely indispensable role to play in labor regulation, particularly in the regulation and improvement of the employment conditions of flexible workers. However, any system of labor regulation will have only limited efficacy in this respect as long as workers in different countries, and in 
different parts of the same country, are compelled to compete with each other for work in national and global labor markets without any effective and centralized system of regulation of these labor markets and a complementary system of social protection.

\section{References}

Arendt, H. (1958). The Human Condition, Chicago: The University of Chicago Press.

Anthony, P.D. (1980). Work and the loss of meaning, International Social Science Journal (32/3) (1980), pp. 416-426.

Aronowitz and DiFazio (1994). The Jobless Future - Sci-Tech and the Dogma of Work, Minneapiolis : University of Minnesota Press.

Durkheim, E. (1960). The Division of Labour in Society, New York: The Free Press of Glencoe.

Ehrenreich, B. and Hochschild, A.R. (2003). Global Woman, London: Granta Books.

Fleming, D. and Henrik S. (2001,June). Towards Reflexive Governance of Management-Labor Relations? The Impact of Corporate Culture and Human Resource Management in Malaysia and Singapore. Paper presented at IIRA $6^{\text {th }}$ European Congress, Oslo, Norway.

Gallin, D. (2000, June). Trade Unions and NGOs: A Necessary Partnership for Development. Paper No. 1, Civil Society and Social Movements Program, United Nations Research Institute for Social Development.

Hirst, P. and Thompson, G. (1999). Globalization in Question: The International Economy and the Possibilities of Governance. Cambridge :Blackwell Publishers.

Kanji, N. and Menon-Sen, K. (2001, August). What does the Feminization of Labor mean for Sustainable Livelihoods? Paper presented at World Summit on Sustainable Development, International Institute for Environment and Development (IIED). London, U.K.

Knudsen, H. (2001, April). Between the Local and the Global-Representing Employee Interests in European Works Councils of Multinational Companies. Paper presented at University of Wollongong, Wollongong, Australia.

Malhotra, K. (1998, April). Globalization and the Economic Growth Paradigm: Some Implications for Labor Migration and Mobility. Paper presented at International Conference on Labor Mobility and Migration in China and Asia, Beijing, China.

MOW (1987). The Meaning of Working, London: Academic Press.

Noe, R. A., Hollenbeck, J. R., Gerhart, B. \& Wright, P. M. (1997). Human Resource Management: Gaining a Competitive Advantage. $2^{\text {nd }}$ Ed. Chicago: Irwin.

Oppen, M. (1988). Structural discrimination against foreigner and work-related health risks. Economic and Industrial Democracy, 20(3), pp. 43-64.

Rix, M. (2001, July). Multinational Enterprises, ILO Core Labor Standards and Low Wage Migrant Workers in South East Asia. Academy of International Business South East Asia.

Region (AIBSEAR) Annual Conference, Jakarta, Indonesia.

Sassen, S. (1998). Globalization and its Discontents, New York: The New Press.

Scholte, J. A. (2000). Globalization: A Critical Introduction, NY : St Martin's Press.

Sennett, R. (1998). The Corrosion of Character - The personal Consequences of work in the New Capitalism, New York: W.W. Norton \& Co.

Warr, P. (1984). Work and unemployment. In: P.J.D. Drenth, H. Thierry, P.J. Willems and C.J. de Wolff, Editors, Handbook of Work and Organizational Psychology, Chichester: Wiley.

Wilpert, C. (1998). Migration and informal work in the new Berlin: new forms of work or new sources of labour?, Journal of Ethnic and Migration Studies, 34 (2), pp. 269-294.

Wilpert, C. (1998). Migration and informal work in the new Berlin: new forms of work or new sources of labour?, Journal of Ethnic and Migration Studies 34 (2), pp. 269-294.

Zuboff, S. (1984). In the Age of the Smart Machine, New York: Basic Books.

De Silva, Sriyan. (1998). Human Resource Management, Industrial Relations and Achieving Management Objectives, Bureau for Employers' Activities, International Labor Organization. [online] Available: www.ila.orv,/public/english/dialogue/actem/papersl (September 15, 1998). 